\title{
Biofabrication of silver nanoparticles from Pseudomonas fluorescens to control tobacco mosaic virus
}

\author{
Taswar Ahsan ${ }^{1,2}$ (D)
}

\begin{abstract}
A microbe-based silver nanoparticle could inhibit the tobacco mosaic virus. In the present study, $\mathrm{AgNO}_{3}$ reacts with Pseudomonas fluorescens CZ strain fermentative broth and formed silver nanoparticles. The crystallinity and purity of silver nanoparticles (AgNPs) were examined by an X-ray diffractometer. Number of Bragg reflection was indexed in the face-centered AgNPs to show a cubic structure. Observation of scan electron microscope (SEM) confirmed the formation of AgNPs. Antiviral effects determined by percentage inhibition of local lesion of tobacco mosaic virus (TMV). Spray of AgNPs and inoculation with TMV assayed analysis revealed percentage inhibition of local lesion 92.70. Effects of AgNPs on the morphology of TMV were observed by a transmission electron microscope (TEM). Micrograph images confirmed the significant effects on the morphology of TMV. Biogenic NP from $\mathrm{AgNO}_{3}$ and fermented broth from Pseudomonas fluorescens could be a potent approach to control the TMV.
\end{abstract}

Keywords: Silver nanoparticles, Tobacco mosaic virus, X-ray diffractometer, Transmission electron microscope, Pseudomonas fluorescens

\section{Background}

Understanding of the virus disease outbreak has an emerging influence on horticultural crops and as well as on natural flora as climate alteration (Jones, 2016). There is an alarming situation that plantassociated viruses could affect the production and quality of the crops, while it is challenging task to manage plant viruses (Worrall et al. 2019). Tobacco mosaic virus (TMV) affects 125 species of important horticulture plants, such as tomato, tobacco, cucumber, and pepper (Islam et al., 2018). There are several approaches in practice to combat plant viruses, like the application of nanoparticles to detect and manage the plant viral diseases. Possibly fabrication of nanomaterials could be framed to deliver the

\footnotetext{
Correspondence: taswar.micro@gmail.com

${ }^{1}$ Faculty of Sciences, University of Central Punjab, Lahore, Pakistan

${ }^{2}$ Department of Plant Pathology, College Plant Protection, Shenyang Agricultural University, Shenyang, People's Republic of China
}

genetic makeup, and as fertilizer and biosensors for plant disease detection. From decades, the applications of nanoparticles (NPs) in crop disease management have evolved significantly (Elmer and White, 2018). Several nanoparticles manufactured by the addition of harmful chemicals, which involved the low conversion of composition and high demand for energy. There is an urgent need to replace hazardous chemicals by developing ecofriendly nanoparticles. Biogenic approaches utilize synthesized nanomaterial from microbes and as well as from the plants (Huang et al. 2007). The application of nanomaterial with biocontrol antagonists could be more significant (Mallaiah, 2015). Several fungal- and soil-borne plant diseases were controlled by silver nanoparticles (Cromwell et al., 2014). Only a few reports of antiviral nanoparticles were investigated by using the nano-clay particles (Mitter et al. 2017), while recently several studies reported that bacterial species are biological control agents against

\section{Springer Open}

(๑) The Author(s). 2020 Open Access This article is licensed under a Creative Commons Attribution 4.0 International License, which permits use, sharing, adaptation, distribution and reproduction in any medium or format, as long as you give appropriate credit to the original author(s) and the source, provide a link to the Creative Commons licence, and indicate if changes were made. The images or other third party material in this article are included in the article's Creative Commons licence, unless indicated otherwise in a credit line to the material. If material is not included in the article's Creative Commons licence and your intended use is not permitted by statutory regulation or exceeds the permitted use, you will need to obtain permission directly from the copyright holder. To view a copy of this licence, visit http://creativecommons.org/licenses/by/4.0/. 
TMV, such as Pseudomonas fluorescens CZ (Shen et al. 2017). By keeping in view the above studies, the present study was carried out by manufacturing nanomaterial from strain $P$. fluorescens with silver nitrate to combat TMV.

\section{Material and methods}

Strain P. fluorescens was supplied by College of Plant Protection, Shenyang Agricultural University, China. The strain was identified and reported as a potent antagonistic agent against TMV (Shen et al., 2017). Submerged fermentation broth was produced and centrifuged it. Broth was used for antimicrobial activity. Make 30\% dilution of the active fraction with distilled water. Bacillus subtilis was used as a test pathogen. Silver nitrate and extracted broth from $P$. fluorescens strain were mixed. The reaction was set up by a mix of $90 \mathrm{ml}$ of $\mathrm{AgNO}_{3}$ with 10 $\mathrm{ml}$ of bioactive substance at $80 \mathrm{c}$ by keeping at $5 \mathrm{pH}$ and stirring it for $2 \mathrm{~h}$ and then put it over 1 day. The upper layer was removed by centrifuge to get rid of the impurities. Separated substance further dried at $80 \mathrm{c}$ for $12 \mathrm{~h}$ and then crushed into a fine powder, and finally, at $700 \mathrm{c}$ for $3 \mathrm{~h}$ calcinated to remove all the impurities (EL-Moslamy Shahira, 2018). X-ray diffractometer was used to calculate the diameter of nanoparticles. SEM analysis was done to observe the shape of the synthesized NPS. TMV obtained from the Lab of Shenyang Agricultural University, Shenyang, China. The viral inoculum was maintained on infected tobacco plants. Humidity and temperature were maintained. Nicotiana glutinosa was transplanted into a small pot in the greenhouse after seedling cultivation, and the same growth of tobacco seedlings was selected for reserve in 5-6 leaf stage.

1) Silver nanoparticles (AgNPs) $(100 \mu \mathrm{l})$ treatment was given $24 \mathrm{~h}$ before TMV inoculation on the leaf.

2) Mix the TMV supernatant with $100 \mu \mathrm{l}$ AgNPs for $10 \mathrm{~min}$ and rub the leaf with the mixture

3) Inoculate the plant leaf with TMV and after $24 \mathrm{~h}$ treated with AgNPs

Five seedlings per treatment were inoculated with 3 leaves per seedling. After the onset, the number of the lesions was investigated and the inhibition rate of the lesions was calculated. To observe the effects of AgNPs and TMV, supernatant was sprayed. For control, TMV was mixed with a 1:1 ratio with distilled water. After 36 $h$, it was photographed. Later, the same plant sample was observed by using the transmission electron microscope (TEM), to determine the effects of nanoparticle on the morphology of TMV.

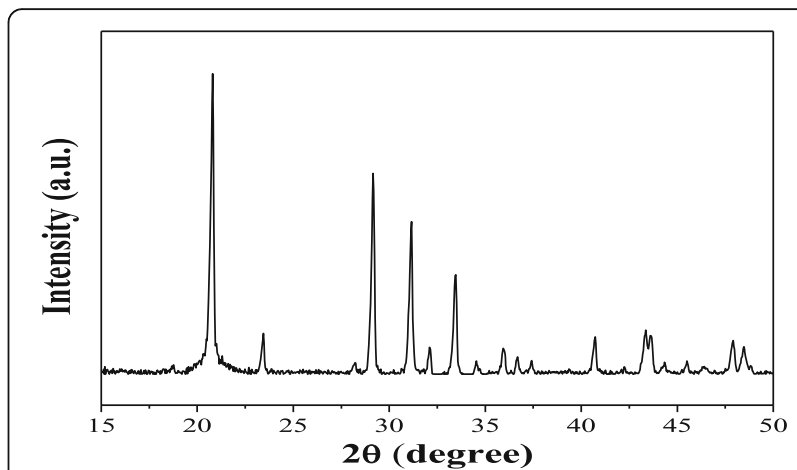

Fig. 1 X-ray diffractometer analysis of AgNPs that biofabricated by Pseudomonas fluorescens

\section{Results and discussion}

In the present study, P. fluorescens and $\mathrm{AgNO}_{3}$ was used to synthesize AgNPs. This strain was previously reported as a potent antagonist against TMV (Shen et al. 2017). The fermented broth was bioassay against the (test pathogen) Bacillus subtilis. Strain $P$. fluorescens had a strong antibacterial activity and indicated that this strain had a potent efficacy against the microbes. So it could be an efficient agent to produce antiviral nanoparticle with $\mathrm{AgNO}_{3}$. Several microbes, such as fungus, yeast, and bacteria, have applications in the synthesis of silver- and goldbased nanoparticles (Huang et al. 2007). Crystallinity and purity of NPs were examined by X-ray diffraction (XRD). The XRD pattern of AgNPs was facecentered cubic (Fig. 1). Diffraction peaks at 2 theta Bragg reflection, which indicated the crystalline nature of the nanoparticles. Sharpness of peaks indicated the purity of the synthesized NPs. Biological synthesis of silver nanoparticles (AgNPs) from the $\mathrm{Ba}$ cillus brevis (NCIM 2533) had crystalline nature (Saravanan et al. 2018). The result is supported by the

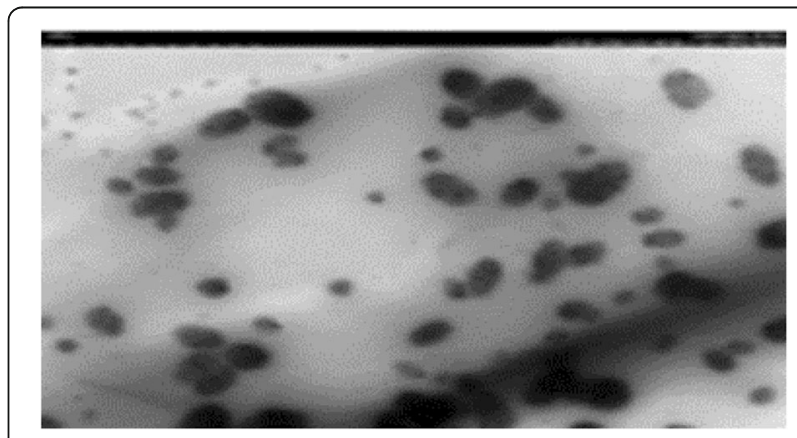

Fig. 2 Scan electron microscopic analysis of AgNPs that are biofabricated by Pseudomonas fluorescens 


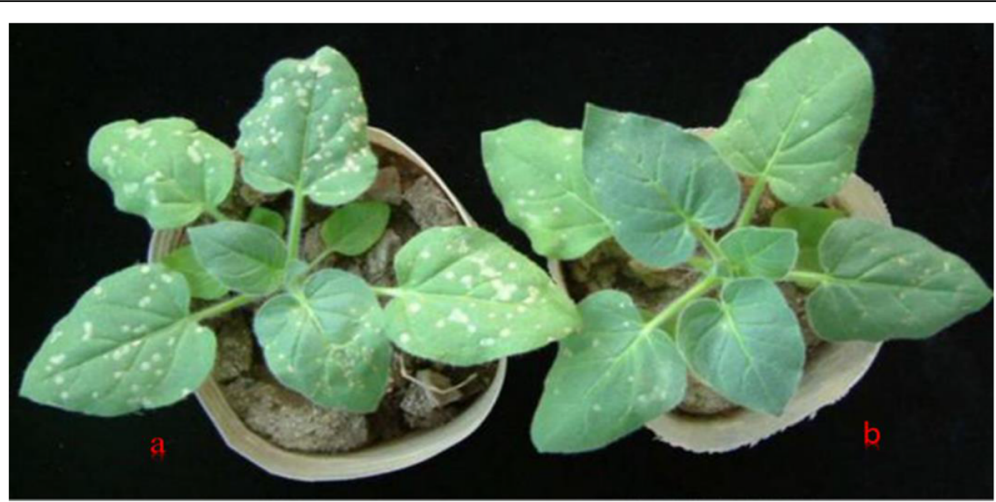

Fig. 3 Control effect of the AgNPs on Nicotiana glutinosa, (a) represented the control. Inoculated only with TMV broth, while (b) treated with AgNPs and inoculated with TMV. Control showed maximum lesion but the treated plant showed maximum reduction of TMV

argument of SEM observation indicated that there were slight variations in the size of AgNPs. The shape of the NPS was spherical and irregular in pattern (Fig. 2). The black dot indicated the capping of the materials. Size of the AgNPs could be between 10 and $100 \mathrm{~nm}$. Silver nanoparticles mostly have a size range from 8 to $100 \mathrm{~nm}$ (Ahmed et al. 2016). The physiochemical characteristics of nanoparticle significantly influence toxicity and efficacy. AgNPs was assayed against TMV. Results showed that NPS could control TMV. Inhibition percentage on the lesion, in $24 \mathrm{~h}$ before inoculation treated the sample, was $86.54 \%$, while the sample treated and inoculated at the same time had more potent inhibitive effects. Before it was introduced to the plant, it was mixed for $10 \mathrm{~min}$. The inhibition rate of the lesion was $92.70 \%$ and post 24-h inoculation treatment had 41.43\% inhibition effect. The results showed that the NPS had good inhibition effects on TMV. Microbebased nanoparticle have good antimicrobial affects (Saravanan et al. 2018). In control figure, (Ck) showed lesion on the leaf, while treatment with NPs reduced the lesion on the leaf (Fig. 3). The results showed that after $30 \mathrm{~min}$ of mixing the purified virus sap with 20 times diluted solution of extract, it changed the morphology of virus particles and changed significantly than the control, indicating that extract had certain destructive effects on virus particles (Fig. 4). Electron microscopic analysis revealed morphological abnormalities in the treated sample. While in the control sample, there were non-significant changes that occurred. Silver-based nanomaterials are stated as antimicrobial substances since the last 10 years (Divya et al. 2019). So the overall results indicated that AgNPs had potent effects on TMV. According to our knowledge, this is the first report to control RNA-based viruses by the microbe-based silver nanoparticle. A detailed study should be brought up by using PCR or ELISA to make a strong evidence of action of AgNPs from $P$. fluorescens.

\section{Conclusion}

Biological fabrication of AgNPs was carried out by mixing extracts of $P$. fluorescens and silver nitrate. Characterization of NP indicated a balanced and costeffective natural substance. Antiviral activity of AgNPs showed potent effects against RNA-based plant virus. This finding could help to meet the emerging need of environment-friendly compounds for the disease management of the crop.
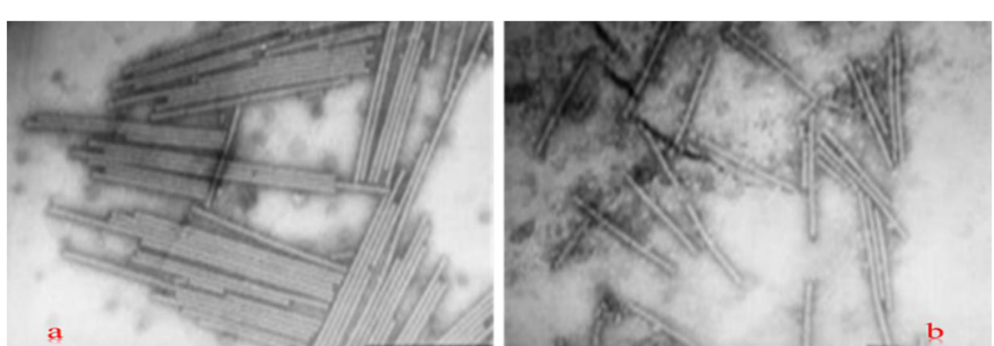

Fig. 4 Analysis of transmission electron microscope by the activity of AgNPs on morphology of TMV, a controlled and $\mathbf{b}$ treated with AgNPs. In the control, morphology of TMV is smooth and normal, while in the treated sample, the morphology of viroid is irregular 


\section{Abbreviations}

AgNPs: Silver nanoparticles; SEM: Scan electron microscope; TMV: Tobacco mosaic virus; TEM: Transmission electron microscope; NPs: Nanoparticles

\section{Acknowledgements}

The author is thankful to the Professor Wu Yuanhua (Department of Plant Pathology, College Plant Protection, Shenyang Agricultural University, P. R. China) for providing the microbes, materials, and equipment.

\section{Author's contributions}

TA designed the study, did the analysis, and wrote the manuscript. The author read and approved the final manuscript.

\section{Funding}

Not applicable

\section{Availability of data and materials}

Not applicable

Ethics approval and consent to participate

No data which needs approval was used in this article.

\section{Consent for publication}

Not applicable

\section{Competing interests}

The authors declare that they have no competing interests.

Received: 18 March 2020 Accepted: 21 May 2020

Published online: 29 May 2020

\section{References}

Ahmed S, Saifullah MA, Swami BL, Ikram S (2016) Green synthesis of silver nanoparticles using Azadirachta indica aqueous leaf extract. J Radiat Res Appl Sci 9:1-7

Cromwell WA, Yang J, Starr JL, Jo Y-K (2014) Nematicidal effects of silver nanoparticles on root-knot nematode in bermudagrass. J nematol 46:261

Divya M, Kiran GS, Hassan S, Selvin J (2019) Biogenic synthesis and effect of silver nanoparticles (AgNPs) to combat catheter-related urinary tract infections. Biocatal Agric Biotechnol 18:101037

Elmer W, White JC (2018) The future of nanotechnology in plant pathology. Annu Rev Phytopathol 56:111-133

EL-Moslamy Shahira H (2018) Bioprocessing strategies for cost-effective largescale biogenic synthesis of nano-MgO from endophytic Streptomyces coelicolor strain E72 as an anti-multidrug-resistant pathogens agent. Sci Rep $8: 1-22$

Huang J, Li Q, Sun D, Lu Y, Yuanbo S, Yang X, Wang H, Wang Y, Shao W, He N (2007) Biosynthesis of silver and gold nanoparticles by novel sundried Cinnamomum camphora leaf. Nanotechnology 18:105104

Islam W, Qasim M, Ali N, Tayyab M, Chen S, Wang L (2018) Management of tobacco mosaic virus through natural metabolites. Records of Natural Products 12:403

Jones, RAC. 2016. 'Future scenarios for plant virus pathogens as climate change progresses.' in, Advances in virus research (Elsevier)

Mallaiah B (2015) Integrated approaches for the management of crossandra crossandra infundibuliformis I Nees wilt caused by fusarium incarnatum desm Sacc

Mitter N, Worrall EA, Robinson KE, Li P, Jain RG, Taochy C, Fletcher SJ, Carroll BJ, Lu GQM, Xu ZP (2017) Clay nanosheets for topical delivery of RNAi for sustained protection against plant viruses. Nature plants 3:1-10

Saravanan M, Barik SK, MubarakAli D, Prakash P, Pugazhendhi A (2018) Synthesis of silver nanoparticles from Bacillus brevis (NCIM 2533) and their antibacterial activity against pathogenic bacteria. Microb Pathog 116:221-226

Shen L, Li F, Jiao Y, Sun H, Wang F, Yuanhua W (2017) Cloning, expression, and purification of an antiviral protein from Pseudomonas fluorescens $\mathrm{CZ}$ and its antagonistic activity against tobacco mosaic virus. Biocontrol sci technol 27 144-148

Worrall EA, Bravo-Cazar A, Nilon AT, Fletcher SJ, Robinson KE, Carr JP, Mitter N (2019) Exogenous application of RNAi-inducing double-stranded RNA inhibits aphid-mediated transmission of a plant virus. Front Plant Sci 10:265

\section{Publisher's Note}

Springer Nature remains neutral with regard to jurisdictional claims in published maps and institutional affiliations.

\section{Submit your manuscript to a SpringerOpen ${ }^{\circ}$ journal and benefit from:}

- Convenient online submission

- Rigorous peer review

- Open access: articles freely available online

- High visibility within the field

- Retaining the copyright to your article

Submit your next manuscript at $\boldsymbol{\nabla}$ springeropen.com 